\title{
ЗАЩИТА ИМУЩЕСТВЕННЫХ ИНТЕРЕСОВ ПРАВООБЛАДАТЕЛЕЙ ПРИ НЕЗАКОННОМ ИСПОЛЬЗОВАНИИ ПРОИЗВЕДЕНИЙ
}

\author{
(c) 2018 Данилов Юрий Сергеевич \\ Генеральный директор ООО «ЮСД Групп» \\ 129110, г. Москва, пр-кт.Олимпийский, д. 16, стр.5
}

Статья посвящена рассмотрению проблем, связанных с защитой имущественных интересов авторов и иных правообладателей за счет взыскания компенсации за нарушение исключительного права на произведение и применения иных способов защиты интеллектуальных прав, предусмотренных законодательством Российской Федерации. Автор отмечает, что отсутствие базовых принципов, которые должны лежать в основе обеспечения защиты имущественных прав авторов и правообладателей, приводит к непоследовательному развитию правового регулирования, а также препятствует формированию устойчивой и единообразной судебной практики. В статье обосновывается вывод о том, что основным принципом, на котором должны основываться положения законодательства о защите прав авторов и правообладателей при нарушении исключительных прав, должен быть принцип полного возмещения убытков, закрепляемый пунктом 1 статьи 15 ГК РФ, а основной целью применения законодательных положений о взыскании компенсации за нарушение исключительного права на произведение должно признаваться наиболее полное восстановление имущественной сферы правообладателей.

Ключевые слова: произведение, автор, авторское право, правообладатель, исключительное право, нарушение авторских прав, защита авторских прав, смежные права, интеллектуальная собственность, интеллектуальные права, убытки, возмещение убытков, судебная практика, нарушение исключительного права, способы защиты.

На протяжении последних десятилетий в Российской Федерации проводится последовательная работа по совершенствованию правового регулирования отношений, связанных с созданием и использованием объектов авторского права и смежных прав, защитой прав и охраняемых законом интересов авторов и иных правообладателей.

Кодификация законодательства в сфере интеллектуальной собственности в результате введения в действие в 2008 году части четвертой Гражданского кодекса Российской Федерации (далее - ГК РФ) позволила объединить в едином нормативном правовом акте законодательные положения, относящиеся к различным объектам интеллектуальных прав.

Однако массовый характер нарушений авторских и смежных прав свидетельствует о том, что несмотря на соответствие отечественного законодательства общепризнанным мировым стандартам и требованиям действующих в данной области международных договоров, законодательство и судебная практика не могут в настоящее время обеспечить надежную защиту прав авторов и иных правообладателей.

Во многом это связано с отсутствием си- стемного подхода при установлении гражданско-правовых способов защиты авторских и смежных прав. В законодательстве закреплены разрозненные и до настоящего времени не согласованные друг с другом положения о взыскании компенсации за нарушения исключительных прав на объекты авторского права, исполнения, фонограммы и иные охраняемые объекты (статьи 1252, 1301 и 1311 ГК РФ), об охране технических средств защиты авторских и смежных прав и защите информации об авторском праве и смежных правах (статьи 1299, 1300, 1309 и 1310 ГК РФ), особенностях привлечения к ответственности информационных посредников (статья 1253.1 ГК РФ), защите личных неимущественных прав (статья 1251 ГК РФ) и др.

Отсутствие базовых принципов, которые должны лежать в основе обеспечения защиты прав и законных интересов авторов и правообладателей, приводит к непоследовательному развитию и усложнению правового регулирования, а также препятствует формированию устойчивой и единообразной судебной практики.

В результате, несмотря на активное использование правообладателями предоставляемых законодательством возможностей, уровень на- 
рушений авторских и смежных прав по-прежнему остается высоким, а принятие правообладателями мер, направленных на защиту их имущественных прав, в том числе путем взыскания компенсации за нарушения исключительных прав, в значительной части случаев не приводит к возмещению причиняемых правообладателям убытков в полном объеме.

Определение размера компенсации за нарушение исключительных прав на произведения на основании формальных критериев (минимальный и максимальный размеры компенсации, двукратная стоимость контрафактных экземпляров или двукратная стоимость прав) дезориентирует правообладателей и судебные органы.

Так, например, рассмотрение дела А5021004/2013 по иску о защите прав на персонажи известного мультипликационного сериала «Маша и Медведь» заняло почти два года и оказалось сопряжено с неоднократными пересмотрами актов, принимаемых судами различных инстанций, включая отмену ранее принятых решений Определением Судебной коллегии по экономическим спорам Верховного Суда Российской Федерации от 11.06.2015 № 309-ЭС147875.

Истец обратился в суд с требованием взыскать с индивидуального предпринимателя компенсацию за нарушения исключительных прав из расчета по 10000 рублей за каждый из семи персонажей, использовавшихся ответчиком при продаже канцелярских товаров - закладок и ластиков с изображениями персонажей. При этом сам факт незаконного использования не оспаривался, сложности возникли исключительно с определением размера компенсации, подлежащей взысканию с нарушителя.

Решением Арбитражного суда Пермского края от 22.01.2014, оставленным без изменения постановлением Семнадцатого арбитражного апелляционного суда от 10.06.2014, исковые требования удовлетворены, с ответчика взыскано 70000 руб. Однако Постановлением Суда по интеллектуальным правам от 08.10.2014 г. судебные акты были изменены, исковые требования по делу удовлетворены частично, а подлежащая взысканию с ответчика компенсация определена в размере 10000 руб.

В обоснование своей позиции Суд по интеллектуальным правам привел довод о том, что незаконное использование нескольких частей (персонажей) одного произведения, даже являющихся самостоятельными объектами авторских прав, составляет одно нарушение исключительного права на произведение. В связи с тем, что все семь персонажей входят в одно произведение, Суд по интеллектуальным правам посчитал возможным взыскать с ответчика компенсацию за одно нарушение в минимальном размере.

Судебная коллегия по экономическим спорам Верховного Суда Российской Федерации не согласилась с данными выводами и направила дело на новое рассмотрение, указав на необходимость определить, какие именно из использованных персонажей могут признаваться самостоятельными результатами творческой деятельности, подлежащими охране авторским правом.

В соответствии с пунктами 3 и 7 статьи 1259 ГК РФ персонаж произведения является объектом авторских прав, если такой персонаж является самостоятельным результатом творческого труда автора и выражен в объективной форме. В связи с рассмотрением вышеуказанного дела в пункт 9 Обзора судебной практики по делам, связанным с разрешением споров о защите интеллектуальных прав, утвержденного Президиумом Верховного Суда Российской Федерации 23 сентября 2015 г., включено указание на то, что «истец, обращающийся в суд за защитой прав на персонаж как на часть произведения, должен обосновать, что такой персонаж существует как самостоятельный результат интеллектуальной деятельности».

Данное требование в определенной мере противоречит подходу, закрепляемому абзацем вторым пункта 28 совместного Постановления Пленума Верховного Суда Российской Федерации, Пленума Высшего Арбитражного Суда Российской Федерации от 26 марта 2009 г. № 5/29 «О некоторых вопросах, возникших в связи с введением в действие части четвертой Гражданского кодекса Российской Федерации», согласно которому при анализе вопроса о том, является ли конкретный результат объектом авторского права, надлежит иметь в виду, что пока не доказано иное, результаты интеллектуальной деятельности предполагаются созданными творческим трудом.

Противоречивыми оказались также рекомендации, содержащиеся в упомянутом выше Обзоре судебной практики по делам, связанным с разрешением споров о защите интеллектуаль- 
ных прав, в пункте 10 которого указывается на то, что «незаконное использование части произведения, названия произведения, персонажа произведения является нарушением исключительного права на произведение в целом, если не доказано, что часть произведения является самостоятельным объектом охраны. Совместное использование нескольких частей и (или) персонажей одного произведения образует один факт использования». В связи с этим делается вывод о том, что компенсация за нарушение исключительных прав при размещении на товаре нескольких персонажей одного мультипликационного сериала, подлежит взысканию как компенсация за одно правонарушение. Данный вывод подтверждается также судебной практикой (судебные акты по делам №№ A357619/2013, A45-13982/2013, A41-66126/2013, А40-107382/2013).

В отдельных случаях истцам присуждаются компенсации, величина которых очевидным образом многократно превосходит потенциальный размер убытков, которые были причинены или могли быть причинены правообладателям, причем решение о таких выплатах принимается исключительно по формальным основаниям.

Так, Решением Арбитражного суда города Москвы от 27.07.2010 г.по делу № А40-99593 по иску ООО «Издательство ТЕРРА» к ООО «Издательство Астрель» были удовлетворены требования о взыскании в пользу истца более 7,5 миллиардов рублей компенсации за нарушения исключительных прав при издании произведений фантаста А. Беляева. Впоследствии данное решение было отменено Постановлением Федерального арбитражного суда Московского округа от 05.03.2011 по делу № A40-99593, правильность отмены подтверждена Постановлением Президиума Высшего Арбитражного Суда Российской Федерации от 04.10.2011 № 4453/1.

Постановлением Девятого арбитражного апелляционного суда от 21.11.2016 г. по делу № A40-147121/2015 по иску компания UCF Partners Limited к ООО «ЭДИЛ-ИМПОРТ» были удовлетворены требования о взыскании 461 млн. руб. за использование десяти рекламных роликов длительностью 5 секунд каждый в рекламе Интернет-магазина Holodilnik.ru. Суд определил размер указанной компенсации на основании числа использованных объектов, количества их показов в сети Интернет и на телевизионных каналах, а также с учетом предполагаемого числа зрителей. Постановлением Суда по интеллектуальным правам от 16.02.2017 г. данный судебный акт был отменен.

Отсутствие разработанных единых принципов определения размера компенсации и целей ее взыскания приводит к тому, что судебная практика так и не смогла решить проблему необходимости и порядка обоснования размеров присуждаемой компенсации за нарушения исключительного права.

С одной стороны, законодательство не предусматривает необходимости обоснования принимаемых судами решений о взыскании компенсации за нарушения исключительных прав, о необходимости обеспечения ее соразмерности с убытками, причиняемыми нарушением. С другой стороны, ссылка на отсутствие обоснованности размера взыскиваемой компенсации нередко используется судами вышестоящих инстанций при принятии решения об изменении ее размера или отмене принятого судебного акта.

Дополнительно следует упомянуть о признании Конституционным Судом Российской Федерации подпункта 1 статьи 1301 ГК РФ частично не соответствующим Конституции Российской Федерации (Постановление Конституционного Суда Российской Федерации от 13.12.2016 № 28-П «По делу о проверке конституционности подпункта 1 статьи 1301, подпункта 1 статьи 1311 и подпункта 1 пункта 4 статьи 1515 Гражданского кодекса Российской Федерации в связи с запросами Арбитражного суда Алтайского края»).

В пункте 43.2 упомянутого выше совместного Постановления Пленумов Верховного Суда Российской Федерации и Высшего Арбитражного Суда Российской Федерации № 5/29 от 26.03.2009 «О некоторых вопросах, возникших в связи с введением в действие части четвертой Гражданского кодекса Российской Федерации», содержится указание на то, что «размер подлежащей взысканию компенсации должен быть судом обоснован. При определении размера компенсации суд, учитывая, в частности, характер допущенного нарушения, срок незаконного использования результата интеллектуальной деятельности, степень вины нарушителя, наличие ранее совершенных лицом нарушений исключительного права данного правообладателя, вероятные убытки правообладателя, принимает решение, исходя из принципов разумности 
и справедливости, а также соразмерности компенсации последствиям нарушения».

С учетом пункта 3 статьи 1252 ГК РФ, освобождающего правообладателя, обратившегося за защитой права, от доказывания размера причиненных ему убытков, на суд возлагаются несвойственные ему функции по поиску обоснований размера присуждаемой компенсации при запрете истребования доказательств причиненных правообладателю убытков.

Противоречивым путем развивается судебная практика при решении вопроса о необходимости наличия вины нарушителя в качестве условия взыскания компенсации за нарушение исключительного права на произведение, предусмотренной статьей 1301 ГК РФ.

Так, в пункте 6 Информационного письма Президиума Высшего Арбитражного Суда Российской Федерации от 13.12.2007 № 122 «Обзор практики рассмотрения арбитражными судами дел, связанных с применением законодательства об интеллектуальной собственности», отмечается, что компенсация подлежит взысканию с лица, нарушившего исключительное право на использование произведения, если такое лицо не докажет отсутствие своей вины в нарушении. В пункте 7 упомянутого выше Обзора судебной практики по делам, связанным с разрешением споров о защите интеллектуальных прав, отмечается, что возможность взыскания компенсации за нарушение исключительного права на произведение не зависит от того, знал ли нарушитель о неправомерности своих действий.

Пунктом 3 статьи 1250 ГК РФ предусматривается, что установленные ГК РФ меры ответственности за нарушения интеллектуальных прав подлежат применению при наличии вины нарушителя, на которого возлагается также бремя доказывания отсутствия вины в допущенном нарушении. Меры ответственности за нарушение интеллектуальных прав, допущенное нарушителем при осуществлении им предпринимательской деятельности, подлежат применению независимо от вины нарушителя, если такое лицо не докажет, что нарушение интеллектуальных прав произошло вследствие непреодолимой силы. При этом по мнению профессора Э.П. Гаврилова «меры, направленные на защиту нарушенных интеллектуальных прав, должны применяться независимо от вины правонарушителя» [3, С.91].

Как представляется, отмеченные противо- речия обусловлены стремлением рассматривать компенсацию за нарушение исключительного права одновременно как меру защиты, меру ответственности и средство обеспечения общей и частной превенции в отношении совершаемых массовых нарушений авторских и смежных прав.

В целях устранения указанного противоречия Ф.А. Музыка в своей работе [6] предлагал разделить компенсацию на два вида: «оценочную», взыскиваемую вместо возмещения причиняемых нарушением убытков, и «штрафную», аналогичную по своей сути штрафной неустойке, применяемой в качестве способа обеспечения исполнения обязательств.

Данный подход, оправданный в части деления компенсации на несколько видов, представляется недостаточно обоснованным в части установления «штрафной компенсации», поскольку ее размер не может быть определен на законодательном уровне и при этом отсутствуют договорные отношения между сторонами деликтного обязательства, возникающего в результате нарушения исключительного права. В результате введение «штрафной компенсации» будет сохранять возможности для произвольного завышения или занижения ее размеров.

Представляется важным предусмотреть на доктринальном и законодательном уровне единый принцип определения размера взыскиваемой компенсации, основанием которого может служить цель наиболее полного восстановления имущественной сферы правообладателей при нарушении исключительных прав на объекты авторского права и смежных прав.

Данный подход позволит избежать определения размеров присуждаемой компенсации по формальным основаниям без учета обстоятельств каждого конкретного дела, исключить произвольное снижение размера взыскиваемой компенсации по сравнению с истребуемой правообладателем, а также случаи злоупотребления правами и присуждения компенсации в размере, явно не соответствующем характеру нарушения и его последствиям.

Таким образом, основным принципом, на котором должны базироваться положения законодательства о защите прав авторов и правообладателей при нарушении исключительных прав на объекты авторского права и смежных прав, должен быть принцип полного возмещения убытков, закрепляемый пунктом 1 статьи 15 ГК РФ. При этом должны учитываться предпола- 
гаемые убытки, которые были или могли быть причинены автору или иному правообладателю в результате нарушения исключительного права.

Необходимо разграничивать функции компенсации за нарушение исключительного права, во-первых, в качестве способа возмещения предполагаемых убытков, причиненных правообладателю, и во-вторых, в качестве меры ответственности, применяемой к виновным нарушителям в целях обеспечения общей и частной превенции, поскольку для достижения указанных целей требуется использование различных подходов.

В связи с этим целесообразно выделить в законодательстве компенсацию как способ возмещения убытков, причиненных правообладателю, и штрафную компенсацию, применяемую в качестве дополнительной меры ответственности, при определении размера которой могут учитываться дополнительные обстоятельства.

Определение размера компенсации, взыскиваемой с нарушителя в целях возмещения предполагаемых убытков, должно осуществляться на основе принципов соразмерности и разумности, без учета отсутствия или наличия умысла на совершение правонарушения. Отсутствие вины нарушителя в совершении нарушения исключительного права на объекты авторского права и смежных прав не должно освобождать нарушителя от выплаты указанной компенсации, служащей исключительно целям полного возмещения убытков, которые были причинены или могли быть причинены авторам и иным правообладателям в результате нарушения.

При взыскании штрафной компенсации необходимо учитывать степень вины нарушителя, неоднократность нарушений, принятие или непринятие мер для прекращения нарушения и другие факторы. При этом поведение нарушителя после обнаружения умышленного нарушения исключительного права может учитываться в качестве обстоятельства, позволяющего снизить размер взыскиваемой компенсации, но не должно служить основанием для освобождения от ее выплаты.

Размер компенсации, взыскиваемой с нарушителя исключительного права в целях возмещения убытков, может определяться по выбору правообладателя в соответствии с положениями статьи 15 ГК РФ, а также на основе информации о доходах, получаемых другими правообладателями при отсутствии нарушений исключительных прав в сопоставимых случаях, оценки рыночной стоимости прав на соответствующее использование произведений, сведений о снижении доходов правообладателя, произошедшего в период незаконного использования произведений при отсутствии иных оснований для такого снижения, а также сведений о затратах, понесенных правообладателем на создание произведения либо приобретение исключительного права на его использование.

При этом суд должен иметь возможность с учетом обстоятельств конкретного дела снижать размер взыскиваемой штрафной компенсации по своему усмотрению с учетом принципов разумности и справедливости для исключения случаев присуждения компенсаций, очевидным образом несоразмерных последствиям нарушений, и иных случаев применения законодательных положений вопреки их назначению и с причинением несоразмерных убытков одной из сторон гражданско-правовых отношений.

Принятие предлагаемых мер, как представляется, позволит разрешить существующие противоречия в законодательном регулировании вопросов взыскания компенсации за нарушения исключительных прав на произведения и создаст основу для выработки обоснованной и единообразной судебной практики по указанным вопросам.

\section{Библиографический список}

1. Гаврилов Э.П. Комментарий к постановлению Пленума Верховного Суда Российской Федерации и Пленума Высшего Арбитражного Суда Российской Федерации от 26 марта 2009 года № 5/29 «О некоторых вопросах, возникших в связи с введением в действие части четвертой Гражданского кодекса Российской Федерации» // Хозяйство и право. 2009. № 9. С. 28-42.

2. Дозорцев В.А. Интеллектуальные права: Понятие. Система. Задачи кодификации / Исследовательский центр частного права при Президенте Российской Федерации. Москва. 2005. 416 с.

3. Комментарий к Гражданскому кодексу Российской Федерации (постатейный). Часть четвертая / Э.П. Гаврилов, О.А. Городов, С.П. Гришаев и др. Москва. 2009. 800 с. 
4. омментарий к Гражданскому кодексу Российской Федерации части четвертой (постатейный) / В. О. Калятин, О.М. Козырь, А.Д. Корчагин и др.; отв. ред. Л.А. Трахтенгерц. Москва. 2009. 812 с.

5. Липцик Д. Авторское право и смежные права / Пер. с фр.; предисловие. Москва. 2002. 788 с.

6. Музыка Ф.А. Компенсация как способ защиты исключительных прав на произведения и объекты смежных прав. Диссертация на соискание ученой степени кандидата юридических наук. Москва. 2011. 211 с.

7. Право интеллектуальной собственности / Под ред. И.А. Близнеца. Москва. 2015. 896 с.

8. Ситдикова Р.И. Обеспечение частных, общественных и публичных интересов авторским правом. Москва. 2013. 159 c.

Поступила в редакцию 21.10.2018 